\title{
Three Generations of Women under the Same Roof
}

Work, gender and social integration in a migrant quarter of Shanghai

\section{Tania Angeloff}

Translator. Elizabeth Guill

\section{(2) OpenEdition}

\section{Journals}

\section{Electronic version}

URL: http://journals.openedition.org/chinaperspectives/5384

DOI: 10.4000/chinaperspectives.5384

ISSN: 1996-4617

\section{Publisher}

Centre d'étude français sur la Chine contemporaine

\section{Printed version}

Date of publication: 1 January 2011

Number of pages: $64-73$

ISSN: 2070-3449

\section{Electronic reference}

Tania Angeloff, "Three Generations of Women under the Same Roof », China Perspectives [Online],

2011/1 | 2011, Online since 30 March 2014, connection on 28 October 2019. URL : http://

journals.openedition.org/chinaperspectives/5384; DOI : 10.4000/chinaperspectives.5384 


\title{
Three Generations of Women
} under the Same Roof

\author{
Work, gender and social integration in a migrant quarter of Shanghai
}

\author{
TANIA ANGELOFF*
}

\begin{abstract}
Taking as a starting-point a qualitative survey carried out between June and November 2007 in an old migrant quarter that was in the process of being demolished, men and women aged between 17 and 82 were questioned in-depth on their life histories, with particular attention paid to their relationship to work.** The aim of the research was initially to raise the issue of lines of segmentation and social and geographical - even ethnic - inequalities in relation to employment from a gender perspective. It emerges that the difference between men and women alone cannot explain inequalities in success and integration. A generational approach centred on the women interviewed enabled us to shed light on individual trajectories within a wider historical context, sometimes refuting certain preconceived ideas on such or such a period in history, which though bloody or violent overall, paradoxically had emancipating and integrating effects in terms of employment for certain migrant women.
\end{abstract}

KEYWORDS: Gender, women, generations, migration, history, Shanghai, work, integration

Biographical material is a historical material like any other and is often more complete than any other, but in any case, it is organised differently. The question is to know what to do with it. How to produce, from a body of biographies or from the relationship of a biography to its historical context, a longitudinal understanding where something is gained from starting from a biography and not generic or synchronic observations? - Jean-Claude Passeron (1990)

1 he neighbourhood under study (1) was an old quarter extending around 223,400 sq.m in Putao, a neighbourhood in southeast Shanghai where migrants settled from 1940-1950, and more recently from 1990-2000. Located on the edge of the city, it is considered to be a penghuqu (棚户区) or shantytown by Shanghaians, ${ }^{(2)}$ whereas it is in reality a self-construction neighbourhood where households own their homes on city land they appropriated at the beginning of the 1940s. Certain of the wealthiest, who have moved to a more modern neighbourhood, rent out one or two rooms to newly-arrived migrants. The majority of people in the neighbourhood are more than 40 years old, that is to say 70 percent of the inhabitants, of whom 21 percent are more than 60 years old. Manual workers and retired manual workers make up the most representative socioprofessional category (80 percent). ${ }^{(3)}$ The district as a whole has been renovated numerous times since the early 1990s: demolition of neighbourhoods considered dilapidated with total or partial rehousing of their inhabitants, and the construction of four to five-storey buildings and big tower blocks. In this mingongqu (民工区), ${ }^{(4)}$ which is destined to be demolished in the near future, only those without the means to buy their own home or who waited in vain for the Shanghai local government to rehouse them remain. More and more people from neighbouring or far-flung provinces have been arriving, leading the more well-established inhabitants to ex- press feelings of mistrust or even xenophobia ${ }^{(5)}$ that often run counter to their links of solidarity with their immediate neighbours. However long they have lived in the neighbourhood, several generations live close together, sometimes under the same roof.

How has the social integration of the neighbourhood's inhabitants and their descendants come about over the period beginning in 1949 ? And above all, amongst the inhabitants of this mingongqu, what perception do the women in particular have of their place in the family and society? To answer these questions, the intergenerational angle will serve to give an account of the processes of the breakdown and reconstruction of employment identity over several decades, a process

* Tania Angeloff is Assistant Professor at Paris-Dauphine University, IRISSO.

** This article is the fruit of a group project carried out within the framework of an investigation into work and housing in Shanghai, financed by the CEFC and resulting in the publication of a report entitled Travail et logement à Shanghai: enquête sur la construction de la société urbaine dans la Chine contemporaine (Work and housing in Shanghai:An investigation into the construction of urban society in contemporary China), CEFC, April 2009. I would like to thank Gilles Guiheux and Tang Xiaojing for rereading the first draft of this article, and Jean-Jacques Zimermann for his remarks and criticisms of the final version.

1. The presentation of the neighbourhood is based on Zhao Yeqin's data in Construction des espaces urbains et rénovation d'un quartier de Shanghai: la problématique de la migration et du changement social (Construction of urban spaces and renovation of a neighbourhood in Shanhai: The question of migration and social change), a doctoral thesis in sociology written under the direction of Ding Jinhong and Pierre-Paul Zalio in 2008 at the École nationale supérieure de Cachan.

2. Chen Yingfang, Penghuqu: jiyizhong de shenghuo shi (Shantytowns: Life stories as told by their inhabitants), Shanghai, Guji, 2006.

3. Zhao Yeqin, Construction des espaces urbains et rénovation d'un quartier de Shanghai: la problématique de la migration et du changement social, op. cit., pp. 117-261.

4. The "peasant workers" neighbourhood, another term used to designate migrant workers.

5. In this respect, the gossiping process studied by Norbert Elias and John L. Scotson, Les logiques de l'exclusion (The rationales of exclusion), Paris, Fayard, 1997 (1965), can be found in this mingong neighbourhood, without there being a systematic separation of the space between longstanding residents and newcomers. 
that could serve as a metaphor for the construction, demolition, and reconstruction of the district's buildings. Moreover, the intersectional perspective ${ }^{(6)}$ - through the intersectionality of relationships between gender, ethnicity, and class - would seem useful for highlighting these phenomena. Our starting point is the hypothesis by which different factors and social relationships - gender, work, membership of a generation, even internal migration judged in the light of the importance attached to a permanent certificate of residency or hukou - combine to favour social integration, which cannot be unequivocal. Such integration can be measured both in the light of objective conditions - stability of employment, presence of a social network, educational level, and income - and in the subjective perception of people experiencing a system of social hierarchisation, the criteria of which have evolved but the reality of which has become more marked over the past 20 years. ${ }^{(7)}$

In tackling the individual dimension of history as told by the inhabitants of this neighbourhood, the succession of generations would seem to be an angle of analysis all the more interesting since it enables us to deconstruct an idealised - and highly ideologised - vision of Chinese society, whilst at the same time taking account of changes and historic continuity. After a theoretical presentation of the anticipated problems, we will examine the case of three generations of women living under the same roof (mother, daughter, and grandaughter $\mathrm{Wu}$ ), placing their trajectories alongside each other.

\section{Methodology ${ }^{(8)}$}

Within the framework of a research project on the new Chinese urban society (CEFC, Travail et logement à Shanghai. Enquête sur la construction de la société urbaine dans la Chine contemporaine, op. cit.), the survey was conducted in two parts: on the one hand, a pre-survey in June 2007, on the other, the survey proper in November 2007. With the exception of two interviews, the research took place in the same mingong neighbourhood. Access to the field - renegotiated several times with the head of the neighbourhood committee - was obtained through the good offices of a Chinese doctoral candidate working on urban renovation in Shanghai, who had been living in the neighbourhood for the purposes of her thesis for several years (Zhao Yeqin, Construction des espaces urbains et rénovation d'un quartier de Shanghai: la problématique de la migration et du changement social, op. cit.). The life stories and interviews were obtained with the help of another Chinese doctoral student, who participated in the research by working on the comparative aspect of the employment of women over several generations. ${ }^{(9)}$ The survey could not have taken place without their participation or without that of 60 year-old Mr. Zhou, ${ }^{(10)}$ head of the committee for this neighbourhood of migrants for many years now. In all, 15 in-depth interviews were conducted and recorded. The main thread of the survey was to reflect upon how integration was achieved through work from one generation to another. With the exception of newly-arrived migrants, with whom interviews were carried out in Mandarin to facilitate communication, most of these life stories were told in the Shanghai dialect, hence the indispensable and valuable assistance of the students who spoke it. In all, the interviews concentrated on four families and three generations. Of the different families we met and interviewed, we retained for the purposes of this article the case of the Wu family, three generations of women living under the same roof: the grandmother (68 years old), one of her daughters (42), and her grandaughter (18). The accounts of the other families interviewed served to support or counterpoint the analyses of the $\mathrm{Wu}$ family.

Need it be said? A qualitative survey does not claim to be representative. Its aim is to flesh out a socio-historic structure, identify the processes involved, and understand how different perspectives - social, gender, geographical or ethnic, and generational - intersect and combine to lead to greater or lesser social insertion. In other words, it is a question of comparing socio-historic structures - "big history" - with individual histories "small history" in terms of scale, without favouring either "biographical utopia" or radicalism in form or structure. ${ }^{(11)}$

\section{Gender, ethnic and generational belonging: The structure of social logics}

\section{Different logics face to face}

Working on migrant women and their descendants over three generations calls for the clarification of a certain number of the concepts and terms used in the analysis. The concept of gender is polysemous. It can be understood first of all as the process of constructing masculine and feminine and the resultant differences and hierarchies. It also constitutes an instrument with which to analyse social phenomena, an analysis grid that is not merely secondary in which gender is just a variable or statistical residue, but on the contrary, one of the structural dynamics of the social world.

Internal migration, in the context of present-day China, describes any move within a province or between provinces undertaken at the initiative of the migrants and not of the Chinese government. The migratory phenomenon in contemporary China is mainly motivated by employment for both men and women, and for the latter also by marriage or spontaneous, and not institutionalised, family regrouping. The idea of ethnicity refers as much to this migratory phenomenon itself as to the dominant social representations concerning migrants from provinces that are poorer than Shanghai and who, for this reason, are perceived as "others," outsiders in the city. This otherness is geographical - it is often a question of migrants of rural origin from far-flung provinces - as well as cultural and linguistic (the migrants do not speak the Shanghai dialect). Whilst newly arrived migrants communicate between themselves in their own dialect and in Man-

6. Kimberley Crenshaw (ed.), Critical Race Theory. The Key Documents That Shaped the Movement, New York, The New Press, 1995.

7. Zhou Xiaohong, La classe moyenne chinoise: réalité ou illusion (The Chinese middle classes: Reality or illusion), in Jean-Louis Rocca (ed.), La Société chinoise vue par ses sociologues. Migrations, villes, classe moyenne, drogue, sida (Chinese society seen by the sociologists: Migrations, towns, middle classes, drugs, sida) Paris, Presses de sciences Po, 2008.

8. I would like to extend warmest thanks to Zhao Yeqin for having invited me to enter the field of her doctoral thesis, and to Tang Xiaojing for accompanying and supporting me in the conduct and translation of the interviews and for her thoughts after the survey. I would also like to thank Christian Baudelot for having participated in the first part of the survey in the field in June 2007.

9. Tang Xiaojing, "Femmes au foyer," "filles de fer" et retour au foyer, Genre et travail à Shanghai sur quatre générations, 1949-2007. Enquête dans une usine agro-alimentaire ("Housewives," "iron girls," and return to the home: Gender and work in Shanghai over four generations, 1947-2007: Survey in a food factory), Doctoral thesis in sociology, written under the direction of Wu Gang and Christian Baudelot, 2009 at the École normale supérieure.

10. All names have been changed to protect the participants in the survey.

11. For a theoretical and critical approach to the use of biographies, life stories, and trajectories as material for studies, see Jean-Claude Passeron, "Biographies, flux, itinéraires, trajectoires," in Revue française de sociologie, vol. XXXI, no. 1, 1990, pp. 3-22. 

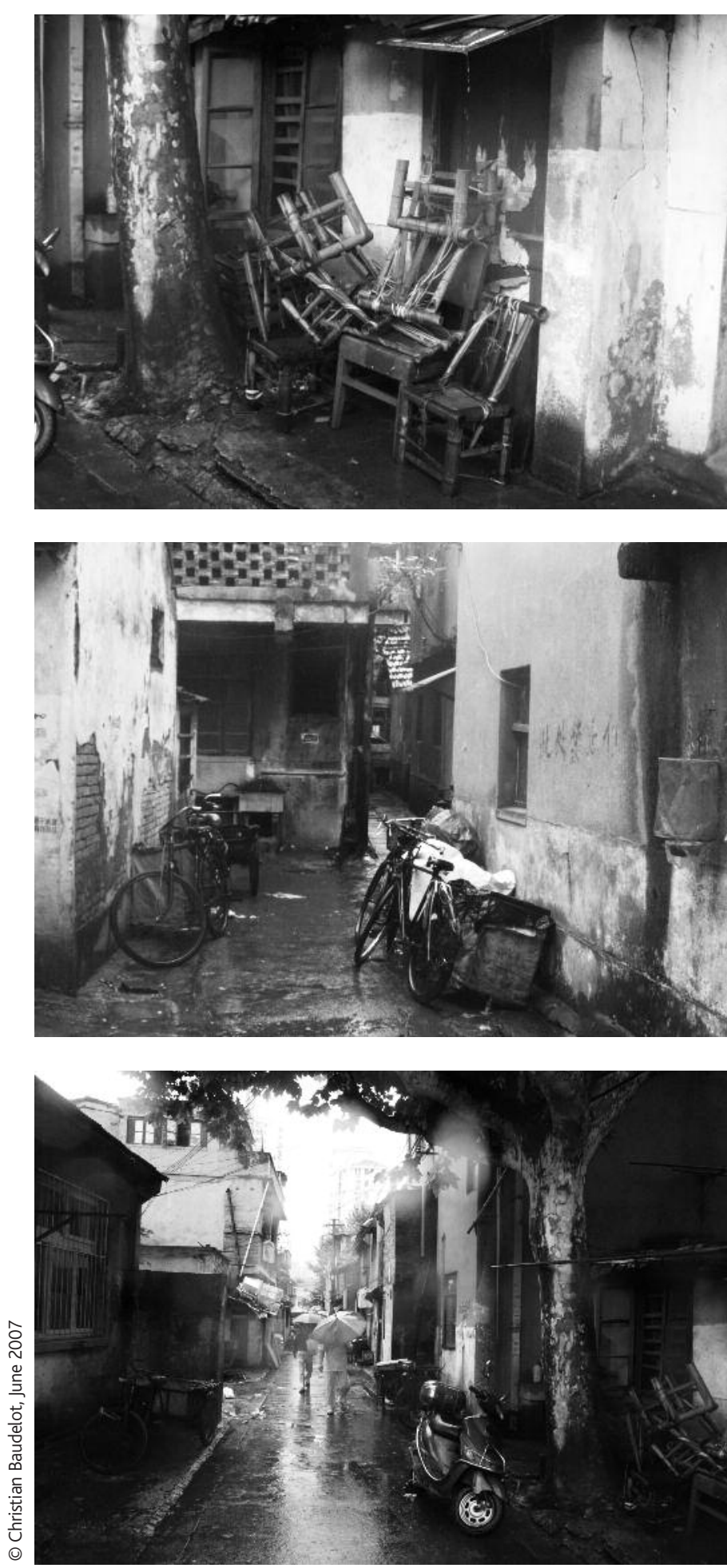

darin with others, the older inhabitants of this mingongqu have forgotten their own dialect and speak the Shanghai dialect. Some of the older inhabitants and their children cannot even speak Mandarin.

An analysis of migration calls for a different analysis grid to deal with social exclusion/integration. A great deal of research exists on the link between immigration and integration, whatever the name given to the latter (insertion, assimilation). (12) In this article, social integration, a concept that must be adapted here to the specific Chinese migratory context, should be understood in its widest sense, that is to say, over and above the immigrant situation. (13) The type of integration studied here, for example, through the life stories of several generations is inspired less by research into the relationship between immigration and integration in itself than it is a continuation of the work of Serge Paugam on precarity ${ }^{(14)}$ and of Claude Dubar on socialisation, construction, and identity crises. ${ }^{15)}$ Within this framework, the main integrating factors of migration - longstanding in the case of the family under study - concern employment, housing, social and legal protection, political participation, and social mobility.

Here, work refers mainly to work as such, understood both as labour, the content of the tasks performed, the job market, and the organisation of this market on the one hand, and on the other, employment understood as a social construction rather than a purely economic variable. (16)

Lastly, the generational paradigm has proved useful in linking individual destinies with big history. As the German sociologist Karl Mannheim (17) stated, a generation is formed as a social group around a major historic event. In China during the twentieth century, and in particular after 1949, the course of individual lives was written into the great social and political upheavals: the Great Leap Forward, Cultural Revolution, and accelerated modernisation and economic liberalism under Deng Xiaoping from 1978 onwards. Therefore, more precisely, the generations in this research are defined as a cohort of births that experienced a major historic event and are structured by this event in their educational, family, and professional lives. To this can be added that this model of a structured trajectory has had an influence - by chance or constraint - that has marked the course of the lives of the interviewees.

Five generations can be identified in the Chinese history of the last 60 years. ${ }^{(18)}$ The Chinese of the first generation, born in the years 1920-1930, were aged between 20 and 30 in 1949 when the Communists came to power. The second generation was born in the 1940s and grew up under the Communist regime. It was educated and socialised between 1949 and 1966. It is a group that is influenced by the beliefs and ideology of the preceding generation as well as by the dominant group values. The third generation grew up during the Cultural Revolution between 1966 and 1978. (19) Marked by a period of extreme fanaticism followed by disillusion, it is known as the "sceptical" or "lost" (20) generation. It is a social group at the crossroads of Communist China and the market economy. The fourth generation was born during the 1960s and went to university after 1980. It is

12. For a synthesis of this research, see in particular Philippe Dewitte (ed.), Immigration et intégration. L'état des savoirs, Paris, La Découverte, 1999.

13. Abdelmayek Sayad, La double absence. Des illusions de l'émigré aux souffrances de l'immigré, Paris, Seuil, 1999.

14. Serge Paugam (éd.), L'Exclusion, l'état des savoirs, Paris, La Découverte, 1996.

15. Claude Dubar, La socialisation. Construction des identités sociales et professionnelles, Paris, A. Colin, 2000 (1991).

16. Margaret Maruani and Emmanuelle Reynaud, Sociologie de l'emploi, Paris, La Découverte, col. "Repères," 1993, p. 3.

17. Karl Mannheim, Le problème des générations, Paris, Armand Colin, col. "Essais et recherches," 2005 (1928).

18. Tania Angeloff, Histoire de la société chinoise. 1949-2009, Paris, La Découverte, col. "Repères," 2010, p. 87 , based on the analyses of Zhang Yongjie and Cheng Yuanzhong, Disidai ren (The fourth generation), Beijing, Dongfang chubanshe, 1988; Tang Xiaojing, op. cit., pp. 49-56.

19. Dating the Cultural Revolution is a weighty social and political issue. Strictly speaking, the political movement launched by Mao Zedong lasted from 1965 to 1969 . However, during the 1980s, the dominant official Chinese history gave it a wider definition, making it end with the death of Mao, or even with Deng Xiaoping's ascent to power in 1978. Western histiography chooses one or the other of these timespans. However, from a social point of view, the Cultural Revolution had repercussions that did not end in 1969 or 1971, in particular the closure of universities and sending of "educated young" to the countryside within the framework of an employment policy. This is why in this article we have adopted the longer timespan to define the Cultural Revolution and the generation affected by it.

20. Michel Bonnin, Génération perdue. Le mouvement d'envoi des jeunes instruits à a campagne en Chine, 1968-1980, Paris, Éditions de l'EHESS, 2004. 
the product of economic reforms as opposed to other generations that were modelled by political reforms. It is a generation erroneously described as "individualist" (21) on account of its mobilisation during the Tiananmen events of 1989. To continue this generational analysis, the fifth generation or "only child generation" is composed of children born in the 1980s and the early 1990s.

So why have we chosen a gender analysis in this article, and why have we chosen to place this at the centre of the analysis?

\section{Gender studies in China}

For a long time, women were conspicuous by their absence from Western studies on China. Such studies take an interest in them simply to comment on the inequalities issuing from the patriarchal and Confucian system and then, after 1949, to sing the praises of the Chinese Communist regime that proclaimed equality for all, including between men and women, and attempted to provide a basis for this through prominent symbols such as heroines who were at first revolutionary, and later from the world of industry. As Lee Ching-Kwan notes, when Chinese studies began to take an interest in women, it was as an additional element in the analysis and not with a view to arriving at an understanding of gender in China, on the one hand as a social and historic construction, and on the other as a process of power and control. This approach was particularly evident and remarkable in relation to the world of work. In the words of Lee Ching-Kwan, "The men and women who have written about Chinese women investigated the effects of industrialisation on matrimonial practices and women's family responsibilities." (22)

In this respect, the work coordinated by Christina K. Gilmartin in 1994, Engendering China: Women, Culture and the State, laid the foundation stone of another approach that uses gender as an analytical paradigm for the history of twentieth century China:

Observing China through the prism of gender is not simply a way of including women in the analysis, it is a way of looking [at society] differently [...]. This has led us to review the basic categories through which we are trying to understand social relationships, institutions and cultural production in China. ${ }^{(23)}$

Using this approach, ethnographic studies on women and work in China have uncovered two recurring themes regarding the trajectories, identities, and culture of Chinese women: the importance of the family, and localism in migratory movements.

Since then, numerous qualitative studies have demonstrated the decisive importance of local networks in the province of origin to migrant women's work. (24) This remark also holds good for men. The division of work that is operating is not only gender-based, but is also dependent on the province of origin, social networks, and collective representations of women from a given province. For example, in the capital, migrants from Anhui are seen as good housemaids by families of intellectuals and managers from Anhui who have moved to Beijing, and in the bourgeois Chinese families that were being reconstituted in the 1980s. (25)

Once again, a cross-analysis of gender, work, and migration and the reciprocal construction of the three domains and processes has proved useful in understanding contemporary Chinese society.
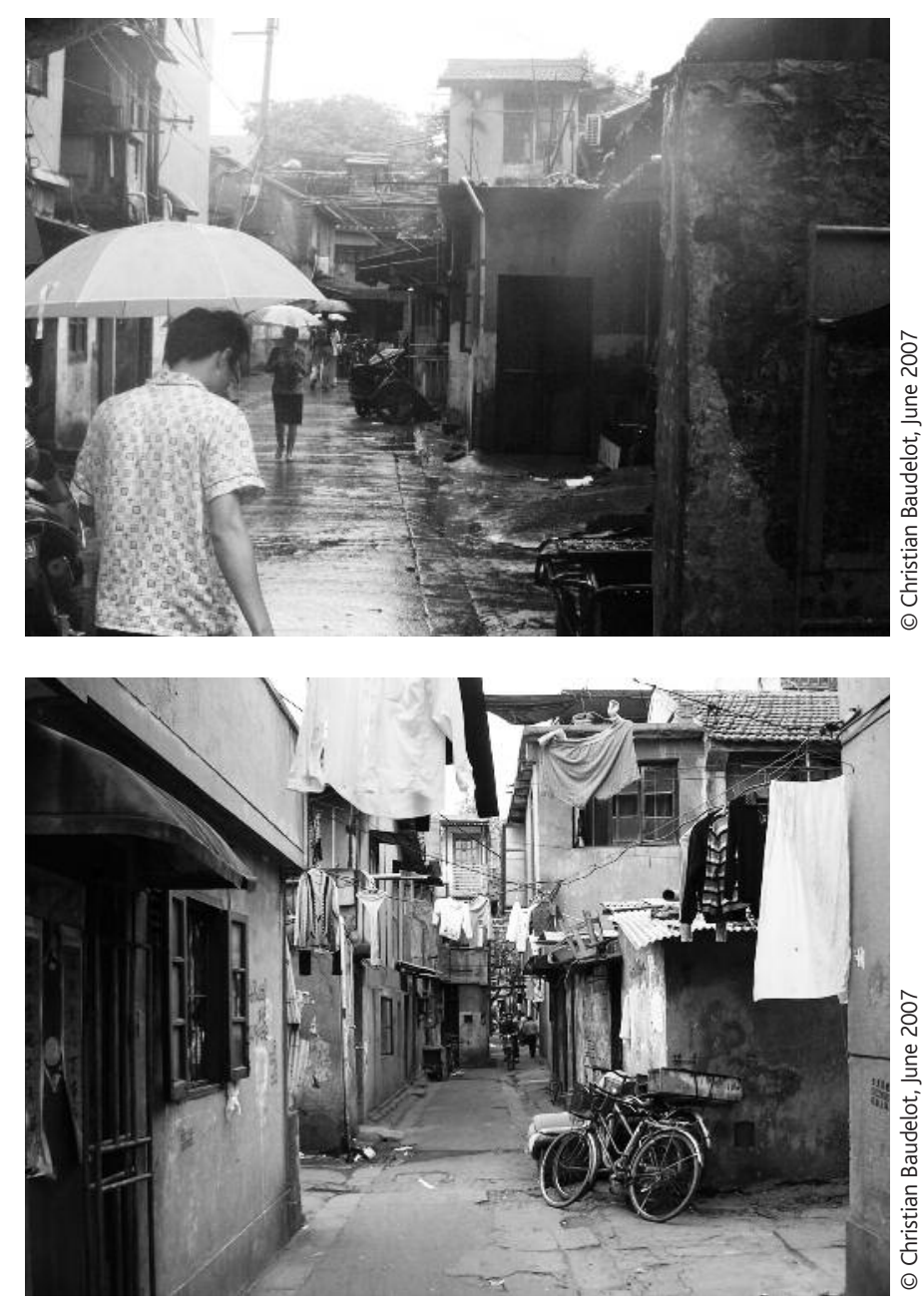

\section{The intersection ${ }^{(26)}$ of paradigms: From women at work to gender-based work}

Women are neither migrants nor migrant workers like other migrants and migrant workers. One only has to examine the division of men and women in internal migration in China to know that even though migration concerns almost an equal number of both sexes today, men are in the majority when it comes to moving within their home province or from one province to another. (27) Moreover, male and female migrants do not do the same jobs, even when they migrate for the same economic reasons, that

21. On this question, see the synthesis by Xu Luo, "The 'Shekou Storm': Changes in the Mentality of Chinese Youth prior to Tiananmen," The China Quarterly, no. 142, 1995, pp. 541-572.

22. Lee Ching-Kwan, Gender and the South China Miracle: Two worlds of Factory Women, Berkeley/Los Angeles/London, University of California Press, 1998, p. 32. See also Janet Salaff, Working daughters of Hong Kong: Filial Piety or Power in the Family?, Cambridge (Massachusetts), Cambridge University Press, 1981.

23. Gilmartin Christina K. et al. , Engendering China: Women, Culture, and the State, Cambridge, MA, Harvard University Press, 1994, p. 2.

24. Quoted by Jacqueline Nivard, Migrantes en Chine, Études chinoises, vol. XXIII, 2004, pp. 383-413. See also Cindy Fan, "Rural-urban migration and gender division of labor in transitional China," International Journal of Urban and Regional Research, 2003, vol. 27, no. 1, pp. 24-47.

25. Jacqueline Nivard, "Migrantes en Chine," art. cit., pp. 387.

26. Elsa Dorlin (dir.), Sexe, race et classe, Paris, PUF, 2009; Sirma Bilge, « Théorisations féministes de l'intersectionnalité $»$, Diogène, $n^{\circ} 225$, janvier-mars, 2009, p.70-88.

27. For a detailed historical analysis of prejudice against migrants from Subei in the province of Jiangsu, see Emily Honig, "The Politics of Prejudice: Subei People in Republican-Era Shanghai," Modern China, vol. 15, no. 3, 1989, pp. 243-274; Tamara Jacka, op. cit., 1998; and Jacqueline Nivard, "Migrantes en Chine," art. cit. 
is to say to escape the poverty of their little provincial town or rural community and enjoy a better life either permanently or temporarily. According to the 2000 national census, more than 144 million people have registered outside their permanent place of residence. (28) Migrant men mainly find jobs in the construction industry or commerce, whilst women are employed in factories, private homes, or in the personal services sector of restaurants, beauty salons, and prostitution. This gender-based division of jobs, in China as elsewhere, is not without significance. (29)

As Lee Ching-Kwan reminds us, work as a social phenomenon is not only the reflection of class structure or ethnic origin but also of a gender system:

This means that the central issue in the question of traditional working conditions and control at work should consider the question of power relationships and work organisations as not solely based on social class but inextricably linked to gender [...]. Not content to include the question of the place of women in the analysis of work and its conditions, we must now analyse the way in which work produces gender relationships whilst at the same time being produced by them: gender as a means of control and as the organising principle of class relationships in production, and work as a place where gender relationships are constructed, formed and reproduced. (30)

From feminist theory (as it was generally known in the 1960s) to gender studies, ${ }^{(31)}$ research has evolved greatly. Feminist research centred on employment situations in the 1980s has been superseded by historical analysis of the patriarchal system, which was Marxist and neo-Marxist in inspiration. Feminist methodology has turned towards ethnographic surveys that highlight the interdependence of gender, class, age, and ethnic inequality. In the 1990s, these approaches brought to light the existence of differences within the group of men and within the group of women, even though we can compare these two social groups for the purposes of analysis in the world of work and society in general.

In studying work today in China, one cannot but observe lines of segmentation not only between urban and rural workers, but also in cities between workers of urban origin and rural origin, between men and women, workers and migrant workers, as well as between migrant workers according to their province of origin, and even sometimes the region within a given province.

Questions must therefore be asked on the respective role and the interdependence of these processes in a given situation observed during the survey.

\section{Three generations under the same roof: From successful integration to the disillusions of the market?}

The generational approach, already used in the case study of the migrations of women in China ${ }^{(32)}$ proved necessary in the field to explain some of the major differences between migrant women. It was also useful in describing migratory phenomena and their evolution in the course of Chinese history from 1930 to the present. Indeed, certain constants emerge. In 1930, for example, migrants arriving in Shanghai and other economically active cities were motivated by poverty. When one studies the trajectories of women from different age groups - 55-70 years old, 40-55, 25-40 and below 25 years old - questions arise on the differences in matters of work, social success, and family situation. In our introduction, we asked how individuation reflects socio-historical structure. To try to answer this question without excluding the trajectories of other mingong families and the life stories of the men interviewed, we will now concentrate on three generations of women living under the same roof, three contrasting itineraries from grandmother to daughter and grandaughter.

\section{Sociodemographic presentation of three comparative portraits}

We will focus on an analysis of three generations of women living under the same roof in the neighbourhood where the grandmother settled in 1962, just after her marriage. It is, in fact, one of the rare families for which we managed to obtain interviews with three generations, and also the only one where those interviewed lived in the same house. The men of the family could not or would not give an interview, since they were either seriously ill, in the case of the grandfather, or absent, in the case of his son and grandson while we were in the field.

At the age of 68 , Wu Ling belongs to the first generation, that of the Liberation. She received us in her dining-room on the day of the interview. She was dressed with care and answered our questions willingly. The interview took place around her little square table. Wu Ling is from the southern province of Fujian. Her parents "worked in the fields" and were poor peasants. She arrived in Shanghai following the death of her parents when she was only five years old and was taken in by uncles and aunts. She began work young, as soon as she left primary school, and until the Great Leap Forward was a temporary worker, employed in particular to carry stones. In 1959, as a result of the Great Leap policy that encouraged women to work - mainly in industry - she became a hairdresser. This change of job was not to Wu Ling's taste and was made on the basis of a decision by her neighbourhood committee. It is, moreover, interesting to note that what might appear to us, from a Western point of view, to be a social promotion was in her eyes a form of social downgrading (see first extract of interview below). She remained a hairdresser until her retirement, which she took early for health reasons at the age of 41 . Her pension is currently 900 yuan. Added to her husband's pension of 1,250 yuan, this gives the household an income of 2,150 yuan. She has three children: two girls - respectively 42 (Jing) and 38 years old - and a son of 45 . Her son and elder daughter live in the same house that she had built in 1984, in the neighbourhood she has been living in for 45 years. Wu Ling and her husband both have the status of retired workers. Wu's husband worked in a civil engineering factory. Starting as a forklift truck operator, he remained at more or less the same level, going on to work as a plasterer.

28. Quoted by Isabelle Thireau in Thierry Sanjuan (dir.), Dictionnaire de la Chine contemporaine, Armand Colin, Paris, 2007, p. 159."

29. Cindy C. Fan, art. cit., 2003 ; Tamara Jacka and Arianne Gaetano (ed.), On the move: Women in ruralto-urban migration in contemporary China, New York, Columbia University press, 2003.

30. Lee Ching-Kwan, op. cit., 1998, p. 22.

31. The term "gender" gradually rivaled and then supplanted the terms "women" and "feminine" and the expression "relationships between the sexes" in the social sciences. Besides the fact that it places the accent on the dynamic relationships between masculine and feminine without favouring the study of one "social sex" over another, it has the merit of reflecting a social construction that avoids naturalisation -- which the term "sex," despite itself, might designate - and relates to a survey methodology that is empirical and qualitative rather than purely statistical.

32. Delia Davin, "Gender and rural-urban migration in China," Cender and development, vol. 4, no. 1, 1996, pp. 24-30. 
jing, second of the siblings and the eldest of the Wus' two daughters, was born in 1965, which means she was 11 when Mao Zedong died. She was 42 when we interviewed her several months after meeting her mother. She talked to us in the shared room of the house with which we were already familiar. The interview was friendly, although jing was more reticent than her mother. She has a diploma from a vocational college, which is common amongst members of her generation, and she is a skilled worker. She began working in 1983 at the age of 18 . She is a turner-trimmer. Her husband, a technician, has been working since 1992 in an import-export company in Japan, where his salary is higher than in China, although Jing, questioned several times, remained evasive as to the exact sum. She has a salary of a little more than 1,000 yuan. She grew up and has always lived in the neighbourhood, and did not leave her parents' house when she married. The cramped accommodation provided by her work unit - 4 sq.m per person and her parents-in-law's tiny apartment explain this choice. By remaining in her parents' house, she and her husband have a large room to themselves as well as a kitchen and the shared room where the family takes its meals. Over the years, the house has been extended and other rooms added. Jing has one daughter, aged 18.

Ding, Wu Ling's granddaughter, was 18 at the time of the interview. She was under pressure, as she was studying for her entrance exam to the university. Her whole life centres on her investment in education. She says she has few friends, no time for amusements, and stopped seeing her childhood friends in the neighbourhood when she entered high school, which is some distance away. Her mother lets her sleep when she arrives home from school, and wakes her up to eat. Bedtime each evening is delayed by homework. She gets up early to work once again. Ding belongs to the generation of only children whose main investment is in education and who are under severe pressure in this respect.

\section{Successful integration: Women at work}

Out of these three generations of women, the grandmother and mother have had a stable professional life, doing work that pleased them. Even though they do not express it this way, it emerges from the interviews that part of their achievement is the result of the stable jobs they have occupied. Stability of employment is the result of being employed in a state company, in the case of Wu Ling, and in a private company with no layoffs since the introduction of the reforms, in the case of her daughter. However, variations in self-image between these two generations of workers can be explained to a great extent by the different socio-historic contexts.

\section{The Great Leap Forward and the Cultural Revolution: Periods of breakdown in the employment of women?}

From a research point of view, Wu Ling's social trajectory points upward and bears witness to a success that was initially due to the Great Leap Forward. Her temporary jobs as a manual worker did not predispose her to this ascension. Her work became more stable in 1959 when she was recruited through her neighbourhood employment centre to a permanent job as a hairdresser in a state-run hairdressing salon. However, at that time the job was a downward step for women. It was a profession with inferior status, and at first Wu Ling took it as social downgrading, despite its stability and the fact that the work was not so laborious.
It was feudal thinking. Few women touched men's heads... This corresponded to women of inferior status. When a woman carried out this job, she was looked down on. Previously, women were not allowed to touch men's heads.

In social representations, jobs involving bodily contact were stigmatising for women, since they were ambiguous. Hairdressing, seen in the mind of the public as a profession involving the body, was linked with prostitution. For the first few years, Wu Ling felt less free than when she was working as a stone carrier. It is doubtless no accident that she began to enjoy her job after her marriage in 1962, when the spectre of the fallen woman had faded. She then enjoyed to the full her status as a permanent employee.

To understand the importance of stable employment status, a review of the main categories of employment from the 1950s to the present would be useful. Tang Xiaojing has retraced the history of employment for women over this period through a monograph on a food-processing factory in Shanghai. ${ }^{(33)}$ She reminds us that since the beginning of the 1950s, at least two employment statuses exist in industry, including in public state-run companies: permanent workers and temporary workers (real industry temporary workers). This second group was made up largely of women. This shows that despite the regime's egalitarian proclamations, women classed as "housewives" in the city's statistics formed a large reserve army for industry throughout the Maoist era. The state encouraged their permanent appointment in the first years of the regime before cutting back on this considerably. They constituted a mobile, flexible workforce used at certain periods of the year or of history, and were sent home when work fell off. At the time of the Great Leap Forward, they were used a great deal in the cities from 1958 to 1961, in addition to the men employed in industry who were already occupying posts. Some of them were appointed permanently during or after the Great Leap until October 1962, whilst others were sent home and a third group retained the status of temporary worker whilst working in the company until the economic reforms. In the 1980s and 1990s, the first workers dismissed from collective and state companies were women, and amongst them, the temporary workers who had never been appointed to permanent posts. Lastly, it should be noted that amongst the women made redundant after the Great Leap, some had to leave the city with their families. Between 1961 and 1965, six million city-dwellers were sent to the countryside to reduce the rate of urban unemployment (at the same time as the 18 million rural workers in the cities who had been arriving to work there since 1958). (34)

For Wu Ling, the Cultural Revolution represents another important stage in her professional life, for it was during this time, between 1965 and 1968, that she saw her working day of 10 to 12 hours reduced by law to eight hours whilst the provision of child care facilities for young children in public crèches lightened the burden of work. Her son was three at the time and her daughter jing had just been born. It should be noted that in China, the first decree by the Council of State Affairs on the reduction of the working week dates from 8 June 1956 and recommends an eight-hour day in the building and civil engineering sectors. Subsequently, and up until the Act of 24 January 1994 promulgating the eight-hour day in all sectors and

33. Tang Xiaojing, "Les femmes du Grand bond en avant. Miroirs et masques idéologiques," Travail, genre et sociétés, no. 24, 2010, pp. 61-78.

34. Chan Kam-Wing, Cities with Invisible Walls. Reinterpreting Urbanization in Post-1949 China, Oxford University Press, 1994, p. 38-39. 
branches, the reduction of the working day was achieved through successive decrees, branch by branch.

With the Cultural Revolution, the working day was regulated. Previously, it was left to the goodwill of the salon manager. I could work 10 or 12 hours and he eight hours; there were no rules. After the Cultural Revolution, that was no longer possible. You had to work eight hours a day and overtime was paid [...]. So the Revolution created great upheavals, both in daily life and work. Living standards improved as a result.

Wu Ling is therefore one of the women who in terms of stability of employment benefited from the Great Leap - one of the slogans of which was "liberate women" - although she had not initially seen her hairdressing job as a promotion that was a source of greater liberty. For her, the major turning-point was nonetheless that of the Cultural Revolution, which by reducing working hours in general and above all, in her case, through the introduction and spread of collective childcare that was to become a permanent fixture, lightened the burden of her domestic obligations. The period corresponds to the feminisation of employment in Shanghai and the rest of China and to the re-recruitment of temporary workers removed from employment after the Great Leap. However, amongst the women of her generation, Wu Ling emerges if not as an exception, at least as atypical, as she herself gives one to understand once the recording is finished. Indeed, the norm for uneducated migrant women was to be confined to physically exhausting temporary jobs. Her entry into hairdressing spared her this experience of long-term temporary employment.

Her professional life therefore appears stable, although not spectacular for all that. Amongst other things, it illustrates the social advances in Chinese labour law - reduction in working hours, the creation of collective childcare - at times in Chinese history when many Chinese were encountering difficulties in employment. Admittedly, once stabilised, the professional trajectory of Wu Ling ceased to move upwards. However, in this respect, it was like that of the women of her generation in general. Upward-moving careers in industry are often the result of membership of the Chinese Communist Party and the militancy that results. However, several surveys converge to demonstrate that women, faced with domestic tasks and childcare in a situation where the distribution of work is unequal despite the political rhetoric, are not as free as their masculine counterparts to make a career by joining the Party and participating in evening classes and political meetings. In these circumstances, one might well ask why Wu's husband did not have a career, either. Two explanations might be advanced: his rural, non-Shanghaian origins, and his poor health, which excluded him from active participation in the Party within his company and therefore deprived him of professional promotion. To our knowledge, although we know that fewer women than men joined the Party, no study exists on the ethnic and geographical origins of its members. It is probable, however, that urban and local origin played a part in the recruitment of its members.

There are worse professional destinies than those of Wu Ling and her husband, however. For example, the mother in the Lao family, aged 82, the longest-established family in the neighbourhood, did not have the same experience, nor did her husband. Was this because she had twice as many children? He remained a forklift truck driver all his life, whilst his wife started out as a temporary worker, then became a housewife due to the lack of public childcare in the 1940s and 1950s and state encouragement of the "housewife" category as a reserve of flexible manpower. Besides, many migrants arriving in Shanghai during the first years of the Communist regime alternated between temporary jobs and unemployment. ${ }^{(35)}$

\section{Born under the Cultural Revolution: Effects on career}

Born in 1965, Jing grew up under the period of turmoil in the education system at the time of the Cultural Revolution, and while too young to be sent to the countryside, she nonetheless still belongs to the "lost generation." The direction of her trajectory is part of a collective and individual destiny that differed from that of her mother from the outset. Indeed, although unlike her mother, Jing was able to go to school thanks to the democratisation of education when the Communists came to power, she was stalled at the secondary school level as a result of the disorganisation of the education system that accompanied the Cultural Revolution. (36) She did not have the chance to go to university, and after obtaining her schoolleaving certificate she failed to gain entry to her chosen vocational school to study pharmacy. In the 1980 s, vocational schools represented a palliative for study for the youngest members of her generation. Jing then found herself in a vocational school for machine tooling, and soon after that joined a machine tool factory as a skilled worker. Deprived of a chance for professional promotion and having suffered from a still-chaotic education system, her professional destiny appears, in this respect, to be identical to that of other women of her generation.

\section{In 1982, when you finished secondary school, the entrance exam to university had been reinstated, hadn't it?}

Yes, but at the time only a few students could take the entrance exam to university, that is to say, very few. I remember that there were vocational schools, and it was already something to be able to take the entrance exam. But I didn't correctly fill in the table where you state your choice. I didn't get into a pharmaceutical vocational school and found myself in a machine tool company because of that.

She explained that her chances of promotion were already reduced because she was a woman. Promotion signified geographical mobility - toward other provinces, even abroad - which she refused. This is illustrated by an interview with slightly older woman of her generation, whom we will call Wang Fei. For the latter, international mobility was an opportunity she seized all the more eagerly because her husband was stagnating professionally.

Let us compare for a moment the trajectory of Wu jing with that of Wang Fei.

Wang Fei, born in 1954 into a large family of seven children, is eight years older than Jing. Her parents arrived in Shanghai from jiangsu at the same time as Jing's grandmother, Wu Ling. At the time of the interview, Wang Fei lived alone with her husband and their son of 27 in a mingongqu house that had been completely renovated and was still having work done on it. She rented the ground floor out and lived on the first floor. The family owned it with the mother and one of Wang Fei's younger brothers.

35. Tang Xiaojing, op. cit.

36. Cf. Suzan Pepper, China's Education Reform in the 1980s: Policies, Issues, and Historical Perspectives, University of California, 1990 
The destiny of this woman, although of the same generation as Wu Jing, appears very different. At the time of the Cultural Revolution, mistakenly fearing ${ }^{(37)}$ she would be sent to a far-flung province after school, Wang Fei anticipated her departure as a young educated person (zhiqing 知青) in 1970 to join her elder sister in the neighbouring province of Zhejiang. She stayed there nine years until 1979, the year in which political relaxation made it possible for one of the children of siblings sent to the country under the Cultural Revolution to return to the city. She married soon after her return, and her son was born a few years later. Before her marriage she passed the entrance exam into a state textile company, where she worked as a quality controller until 1994. She then left to work in Nicaragua until 1997 for her company, which had been semi-privatised with Taiwanese capital. In 1999, she was 45 and found herself in early retirement, yet did not stop working for all that. For the next six years, she undertook shorter missions for the same employer to several South American countries, Los Angeles, and Cambodia before finishing with a post in Qingdao, Shandong Province in 2003, a position she had left about a year before our interview. Wang Fei's professional mobility, which she interprets as "luck" in her career, was in fact the result of choice and the situation of her husband. An electrician made redundant from a state-owned company, at the time of the interview he was unemployed and struggling to find work after setting up a small transport company that very quickly came to grief, swallowing up part of the money the couple had acquired through Wang Fei's expatriate salary.

Compared to Wu jing and her husband, traditional gender relationships seem to have been reversed between Wang Fei and her husband. Indeed, the wife met the needs of the family much more effectively than if she had remained in Shanghai in the 1990s and 2000s. In return, as far as the division of labour is concerned, her husband takes charge of the domestic tasks: shopping, cooking, housework, and laundry. Since she left China because her husband had difficulty finding work, Wang Fei recognises the psychological cost this represented for herself and her family. This does not prevent her from sounding extremely positive about her career and repeatedly describing herself as "lucky."

Initially, I thought it wouldn't be hard to work abroad on account of my experience as a zhiqing (young educated person) in the countryside. I was used, or at least I thought I was, to being separated from my parents and family and working in an unfamiliar place. But it was different because I was single then. During the first years, I thought a lot about my family, my mother, and my son. I worked ten hours a day and overtime at the weekends [...] The rhythm was twice as intensive as in China. A Taiwanese employee represented at least two Chinese employees. As quality controller I had to look after 90 machines and 110 people, whereas in China there would have been five for the same workload. We were dead with fatigue. The pressure was very intense. [... I In all, I remained away from Shanghai and far away from my husband and son for around ten years, and they did not want me to continue. In 2003, when I came back, I stopped going abroad and reduced my missions to short stays in neighbouring Chinese provinces.

Unlike Wu Jing, who explains that it was important for her to remain near her mother and the daughter in whom she had invested high hopes of academic and social success, Wang Fei emphasizes the social cost of profes- sional mobility. Indeed, in her eyes, the academic and social failure of her son, whose attitude she finds immature, can be explained by her own absence during the decisive years of his pre-adolescence and adolescence.

Lastly, the reversed economic power relationship of the couple has made her husband "ill at ease," encouraging her to be conciliatory over family decisions with which she is not always in agreement, as though to compensate for her lengthy absence and economic autonomy.

My husband looks after me very well. Even before I left to go abroad, it was he who took charge of all the domestic aspects at home. [...] It has to be said that the people in my family are bizarre. My brother does nothing in the house, it's my sister-in-law who looks after that side of things. In my parents' house, it's always my father who does the cooking. As for the children, really, neither boys nor girls take on any domestic responsibilities.

More generally, in couples of this generation born during the Cultural Revolution, one of the spouses, rarely both, plays the professional mobility card, and it is more often the man than the woman. Bringing up the children and looking after the home generally falls to the wife. In this respect, Wu jing is typical of her generation, a generation that as a whole has been "sacrificed." It was her husband, better qualified than she, who left to work in Japan at the beginning of the 1990s as a technician in a mixed capital enterprise. Wang Fei's trajectory seems more original. However, in the detail of the analysis, it is interesting to note that despite this difference, the "price" the two women, representative in this respect of their generation, have had to pay is separation from their husbands and family for professional reasons for long periods of time. They see this separation as having a psychological cost for them and their family. Wu jing admits that her daughter misses her father and that he did not see her grow up, and Wang Fei that her son suffered from her absence for several years.

\section{The grandaughter $\mathrm{Wu}$, an emblematic figure of the only child generation}

Of the three women in the Wu family, Ding seems to bear all the promises of social and professional success by virtue of her educational investment. She also appears the least "happy" and fulfilled, and the most subject to the pressure for social success. She bears the double burden of her generation as both an only child and a high school student confronted with an extremely competitive education system. It would be vain to make a precise comparison of her trajectory with that of her mother and grandmother, since she has not yet entered the employment market. Suffice it to say that of the three women, it is Ding who is most likely to enter higher education but who is also the most exposed to academic competition and doubtless, later on, professional competition. Highly introverted during the interview, she several times expressed the burden parental and social expectations represent for the young people of her generation. Moreover, as the only child of parents deprived of education, these weigh all the more heavily on her.

More generally, the interviews conducted in other families confirm the immense hopes of parents regarding their only children and the disappointment when these aspirations are not fulfilled. The Lao family is proud 37. Being sent to the country was no longer compulsory for young high school pupils and students, which
she did not know at the time. 
to announce that their only son studied in Korea for several years. His cousin, 22 years old in 2007, did not have that good fortune. The interview with this young man and his mother took place in the Lao home in the presence of the parents, and one senses the weight represented by the scholastic failure on this young man and his parents. After leaving a vocational information technology high school at an early age, he did not wish to pursue his education. He then took a training course independently, after which he moved between several dead-end jobs, leading to a job as a salesman in a small company. At the time of the interview he was unemployed as a result of a thyroid condition for which he is receiving treatment. Both his parents found themselves unemployed, his mother at the age of 39, when her job as a bus ticket puncher was automated, and his father at 41 when the textile factory where he was a manual worker closed down. This seems to have played a part in their son's shunning of scholastic competition. For his parents, descendents of migrants, from the "lost generation" growing up under the Cultural Revolution, proud of their Shanghaian identity and in particular of the Shanghai dialect, the social and professional failure of their only child represents failure as a family. Academic success, on the other hand, symbolises successful integration; leaving the mingongqu to study abroad and then live elsewhere are all signs of success for the older inhabitants of the neighbourhood.

\section{Social ascension from generation to generation?}

The question of social ascension from one generation to another has proved delicate. Indeed, on the one hand, it boils down to comparing an individual assessment and a general historic context. On the other, it brings us face-to-face with two different types of assessment criteria: that of the players concerned on the one hand (through the accounts given by these women and the comparisons they make with their siblings, their community, and their generation); and that of research of the other (in the light of the history of Chinese society but also of the whole corpus of interviews given), without these criteria necessarily overlapping.

Consequently, if we look at things from the point of view of the interviewees, the grandmother expresses a positive opinion of her trajectory both in relation to the women of her generation in a comparable situation (in other words migrants, mothers, and living in the same neighbourhood) and in relation to what has been termed "big history," which she considers favourable in her own case. Her eldest daughter, on the other hand, expressed reservations regarding her own professional itinerary, fitting it into two successive historical contexts, that of the "lost generation" and then that of the reforms. However, although she deplores her forced orientation towards a machine tool factory, she recognises that she was lucky not to have been made redundant in the 1990s and 2000s, and considers herself fairly fortunate.

Their successive analyses might give the impression that there are periods of history that are more favourable than others for the employment of women. However, after much debate, the sociological point of view on these trajectories differs considerably, in that it tends to show that no one period is better than another as far as women's employment is concerned. (38) How can a comparison be made under these conditions? A first solution consists of examining employment flows: in the public sector, they have fallen sharply since the introduction of the reforms, and women have been the first to be affected by the redundancies. Then, in the absence of being able to draw on reliable figures concerning rates of activity, since most of these figures are missing for a period of more than ten years or so (from 1965 to 1978), the determining criteria between the Great Leap Forward and the current period may concern employment policies. In this respect, the State is less protective today of Wu Jing and the women of her generation within the context of the liberalisation of the economy and waves of worker redundancies from state-run collective enterprises (39) than it was for her mother, whose appointment to a permanent post allowed her to attach herself to a work unit with all the social security rights that this conferred. It is therefore impossible to make an exact comparison of the itineraries of the mother and grandmother Wu. The evolution of urban employment nonetheless allows us to appreciate that Wu Jing's degree of integration is more fragile than that of her mother, but that at the time of the survey it was compensated for by the professional and geographical mobility of her husband.

In short, social integration can therefore be seen in employment statuses and the levels of education, which rise from generation to generation as a result of the state's insistence on the education system and manual work. Grandmother Wu did not have as much education as her daughter, who in turn was not able to attend the general high school that would have allowed her to take the competitive examination to enter university when it re-opened its doors. The granddaughter, meanwhile, in common with the rest of the only-child generation, has invested heavily in education.

For these former acculturated migrants - acculturation that can be seen in the use of the Shanghai dialect - integration and the construction of a Shanghai identity traditionally took place through employment, then through the development of the education system by the Communist State. The grandmother, Wu Ling, left education after primary school to start working a few years later at the age of 13. Her daughter jing completed high school before entering a vocational college immediately after the Cultural Revolution. She began working at the age of 18. The granddaughter, Wu Ding, was 18 when we met her. Her future looks promising if she passes the university entrance exam, which will allow her to choose what she would like to study at a prestigious university. During the interview, she mentioned her wish to study literature at Huashida (the University of East China). Failure would lead to social downgrading. The integration described was consolidated finally by effective family mutual assistance as well as by the presence of the neighbourhood committee, still very active at the time of the survey, and which created, between inhabitants over the years, a chain of solidarity in the neighbourhood that is all the stronger for being long-established.

Lastly, contrary to what one might have thought, social promotion from one generation to another cannot be assessed in terms of income. Grandmother Wu and her daughter receive almost the same amount (a 900 yuan pension for Wu Ling and a little more than 1,000 yuan in monthly revenue for her daughter). Both, however, find that their living conditions have improved over the years, and that quality of life has been enhanced in terms of consumer goods (air conditioning, television, washing machine, computer, etc.). As regards domestic tasks, they agree that they spend less time on these and are less tired than in the past, and as a result find that their condition as women in society has improved. The subjective vision of the Wu daughter belies

38. Tania Angeloff, "La Chine au travail (1980-2009): Emploi, genre and migrations," Travail, genre et sociétés, no. 23, 2010, pp. 79-102.

39. Liu Jieyu, Gender and Work in Urban China: Women Workers of the Unlucky Generation, Londres/New York, Routledge, 2007. 
the objectivity of a situation in which she has made little progress compared to her mother as a result of historic upheavals following the Cultural Revolution.

However, if we ignore the only income compensated for, in the case of the Wu daughter, by a household income higher than that of her parents, the objective facts of their biography - and the perceptions of these women might lead us to speak of social promotion from generation to generation, even though their home is threatened with demolition and the daughter, Wu Jing, admits having "missed the boat" at the time when she and her husband could have bought a home before property prices went up.

\section{A time of market disillusions?}

This leads us to ask the question, more difficult to quantify, of the feeling of happiness, security, and freedom. Of the three women, it is the grandmother who expresses the least insecurity regarding the future. She has lived with her husband (who suffers from high blood pressure) in the same neighbourhood for almost 50 years with her son, daughter, daughter-inlaw, a granddaughter of 18 , and a grandson seven years old. She is not subjected to the pressures of the labour market and has not been since she became a hairdresser, and she admitted enjoying today's consumer goods and taking pleasure in the presence of her son and daughter and in being a grandmother. If it were not for uncertainty over accommodation - because of imminent expulsion from a neighbourhood threatened with demolition - she would be the happiest of women.

The perception of her daughter Jing is much different. Although she remains very reserved on her feeling of freedom and happiness, says she is happy at work, where the atmosphere between colleagues is, according to her, friendly and pleasant. She is separated from her husband, who has been in Japan for almost the entire life of her daughter, whom she sees suffering terrible academic pressure. A member of the sacrificed generation of the Cultural Revolution, she gives her account, like the other women in her age group, in level tones and with a great deal of sobriety. Nonetheless, she has not progressed professionally, and prospects for promotion in her career are non-existent, since she left the possibility of professional mobility to her husband. The question that concerns her most, besides university success for her daughter, is that of housing. She is more worried than her mother about this. In these circumstances, the fact that her husband is far away doubtless contributes to a strategy of accumulation of capital with a view to buying a flat in a neighbourhood on the edge of Shanghai, even though this was never mentioned during the interview.

As for Wu Ding, the grandaughter, of the three women it is she who appears the most anxious and ill at ease. It is true that she is only 18 and does not know what she wants to do with her life. She is concentrating solely on passing her university exams for studies that she senses are necessary but which she admits do not interest her.

In conclusion, the historical context - the Great Leap policies, the Cultural Revolution, the introduction of economic reforms - seems to have had unexpected effects on individual aspirations, regardless of generation, as the destinies of the male and female migrants and their descendants testify. The darkest and bloodiest periods of Chinese history have, astonishingly enough, allowed certain women such as Grandmother Wu and Wang Fei, who were nonetheless from the sacrificed generation, to be promoted. These social portraits therefore carry contradictions and subtle departures in relation to the institutional history of the work of women in China. In the tradition of ethnographic research, they throw more light on the processes than on the causes of social success and the feeling of success (or failure), since the social fact and feeling can be disconnected. The portraits of the three women we have featured in the analysis give us information on work, the status of the women, and social integration, whilst relegating to the background the geographical origins of the Wu family (in the distant past, it is true, since the grandmother arrived in Shanghai when she was very young, even before the introduction of the hukou). Rather than a reflection of overall reality, they are photographs of women taken in different eras, yet at the same time reflecting the different periods of Communist China and the reforms. Lastly, they give us information on transformations in the status of women, on the resources they have used, and their strategies and limits.

\section{Translated by Elizabeth Guill}

